\author{
Adalat Pashayev ${ }^{1}$, Elkhan Sabziev ${ }^{1,2}$, Arif Hasanov ${ }^{2}$ \\ ${ }^{1}$ Institute of Control Systems of Azerbaijan National Academy of Sciences, Baku, Azerbaijan \\ ${ }^{2}$ War College of the Armed Forces of the Republic of Azerbaijan, Baku, Azerbaijan
}

\title{
THE PROBLEM OF REDISTRIBUTION OF RADIO FREQUENCY USED IN THE ORGANIZATION DIVISIONS
}

\begin{abstract}
The problem of radio frequency distribution is considered in the article, taking into account the regulations and geographical location of the operating units. The problem of assigning radio frequencies from among those assigned for corporate use is studied. Using conformal mapping, it was substantiated that any territory can be divided into zones, each of which will have a border with only three other zones. In this case, in each zone, you can assign frequencies in the amount of one quarter of the total number of available frequencies that do not overlap with frequencies assigned to adjacent zones. A mathematical model of the problem of radio frequency redistribution has been built, taking into account the regulations and the geographical location of the units. The implementation of algorithm allows taking into account the history of frequency distribution by zones, which allows you to completely update the used radio frequencies for a new period of operation. A software module has been compiled that generates frequencies at random from those available for assigning corporate use for each zone. The software module allows fast and frequent reallocation of frequencies by zones, thereby ensuring the safety, reliability and stability of communication between organizational units.
\end{abstract}

Keywords: redistribution of radio frequencies; radio frequency spectrum; radio frequency range; algorithm; geographic location; adjacent zones.

\section{Introduction}

The management of the radio frequency spectrum is an important area of government activity in the direction of increasing the efficiency of using radio frequency resources. The issue of radio frequency allocation is one of the significant tasks in radio transmission, radio communications, radio competition and other similar areas that use electromagnetic waves to transmit information. The choice and allocation of a frequency band for use by certain services, institutions, organizations is determined by their specifics and working conditions. There are various studies devoted to the problems of managing the use of the radio frequency spectrum, including the tasks of their redistribution between different branches of radio frequency operation [1]. At the same time, with the exception of some small deviations, all countries of the world use the same radio frequencies for their intended purpose [2-4].

Radio frequency (RF) spectrum management is an analytical, procedural and political approach to planning and managing the electromagnetic spectrum. Over the past 15 years, the European Union has paid special attention to the development of the digital economy in the internal market through the use and management of the radio frequency spectrum policy [5-8].

In 2002, according to the filing by the Radio Spectrum Management Council and the Parliament, a Framework Directive and an Access Directive were issued, related to the powers of the European Union for the management of spectrum in radio communications $[6,7]$. This document gave a powerful impetus to the development of the EU digital economy.

There are different approaches to the allocation of radio frequencies, depending on the geographical location, interstate relations and the level of development of countries. In Europe, special attention is paid to the issue of planning and allocation of radio frequencies. Taking the limited availability of radio frequency resources into account, they are often classified under two groups - resources for permanent and temporary use. In some cases, the possibility of distributing frequencies by hours depending on the time of day is also considered.

However, every organization that uses radio communication at work, faces the task of distributing the frequency range between its divisions, within the limits of the permissible frequencies allocated for it. To increase the ability to use more different radio frequencies, the geographic area is divided into a reasonable number of distinct zones. This allows to duplicate the used radio frequencies in non-contiguous zones without disrupting the operation of radio equipment in adjacent zones.

Depending on the existing regulations, a number of criteria and conditions can be put forward to the frequency allocation rules, described by a set of regulatory rules. Among them there are the bandwidth for one radio frequency channel, periodic changes in the frequency of the unit, etc.

In this paper, we consider the problem of developing an algorithm for the allocation of radio frequencies, taking into account the regulations and the geographical location of the operation units.

\section{The statement of the problem}

In the general case, an organization is allocated a certain range of radio frequencies for the operation of its subdivisions by setting its lower and upper limits, for example, $30000 \mathrm{kHs}$, and $88000 \mathrm{kHs}$.

Considering the bandwidth for one radio frequency (RF) channel, the total number of $n$ permissible operating frequencies can be determined. For example, if the bandwidth for one RF channel is (grid spacing), $25 \mathrm{kHs}$ then the total number of allowed frequencies will be 34000 . 
However, restrictions are often imposed on some frequencies or on a range of frequencies contained within specified limits, which must be considered in the distribution.

Let the whole territory be divided into a finite number of zones.

In each zone, the assignment of frequencies for one or another corporate user is carried out on the basis of some considerations. The main regulatory restrictions are related to the geographical location of the operational units' location zones.

Their essence is as follows:

- The entire territory is subdivided into separate zones;

- Distribution of frequencies by zones is carried out for a certain period, after which the frequencies are redistributed;

- Distribution of frequencies by zones is carried out for a certain period;

- After a certain period of time, the frequencies are redistributed between the zones again.

Frequency allocation by zones must meet the following conditions:
1) in each limited operational period, for each separate zone, radio frequencies must be allocated in the amount established for this zone;

2) within one zone, all frequencies must be different:

3) the frequencies in the "adjacent" areas must also be different. And in non-contiguous areas, frequencies can be repeated;

4) the frequencies allocated for each zone must be different from the frequencies allocated for the same zone in the previous period of operation.

Adjacent zones are zones that have common boundaries.

For example, Fig. 1 shows 8 zones designated by the symbols A, B, C, D, E, F, K, N. Zone A shares borders with zones B, E and F. Consequently, in each period of under consideration, the frequencies used in zone A cannot coincide with the frequencies used in zones $\mathrm{B}, \mathrm{E}$ and $\mathrm{F}$.

The frequencies used in Zone $\mathrm{C}$ cannot match the frequencies used in Zones B, D, E. And in zone N, any frequencies can be used, since this zone does not have a common border with other zones.

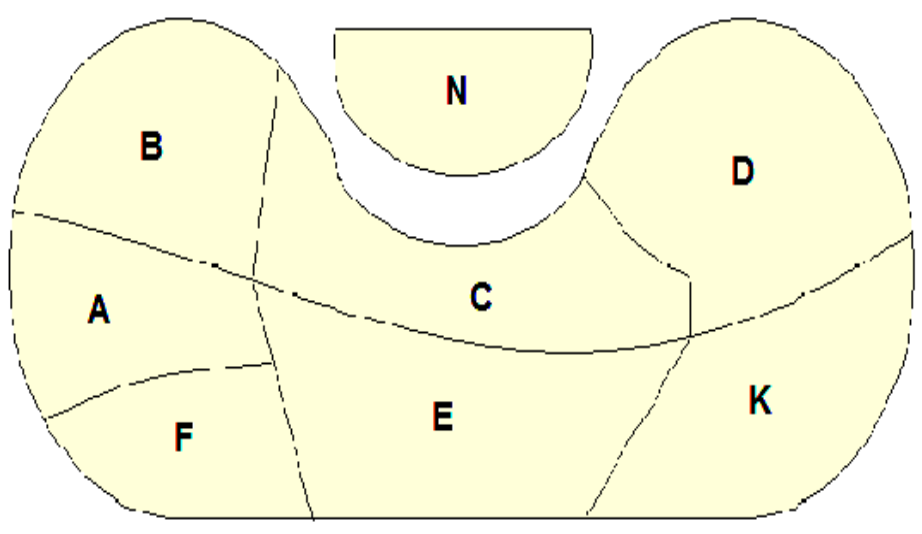

Fig. 1. Geographical location of zones

Let us give an estimate of the number of possible frequency distributions between zones. Let some region be given: country, island, etc. It is required to split this area in such a way that each sub-area (let's call them zones) has a common border with no more than three other zones.

Also, the union of these zones is the same as the original area.

If the area is a rectangle, then one of the options for dividing it into non-intersecting zones with the described properties can be triangulation -, i.e. dividing the area into triangles.

Since any simply connected area can be conformally mapped onto a circle $[9,10]$, it is obvious that any simply connected convex area can be mapped onto a rectangle by continuous mapping. Triangles will be one of the solutions to the problem.

Thus, the distribution of frequencies between a large number of areas is reduced to the problem of frequency distribution between four areas. For each area has a border with three other areas (zones).
Let us have $n$ frequencies at our disposal. They can be numbered, for example, in ascending wavelength or frequency.

Let us denote them by $f_{i}, i=1,2, \ldots, n$. The total number of available frequencies will be $k=\left[\frac{n}{4}\right]$.

Let's assign, for example, for the zone numbered $i$ the radio frequency

$$
f_{j}: j \in[i \cdot k,(i+1) \cdot k] .
$$

This distribution satisfies conditions 1) -3).

In order to satisfy condition 4) we'll assume that the previous distribution was carried out by the same algorithm, but with a shift of the parameter $i$ by one module 4 .

That is, for $i=i_{0}+1$ at $i_{0}<4$, and $i=1$ at $i_{0}<4$.

Thus, with a given frequency allocation algorithm, each zone can be provided with $k$ of different frequencies that satisfy conditions 1) -4). 
Based on this algorithm, it is possible to distribute frequencies not in order, but randomly. In fact, random numbering of frequencies will provide a solution to this problem. Here is an implementation of algorithm.

\section{Algorithm for generating a list of frequencies}

Let's denote the set of all admissible frequencies with $F$. This set, obviously, contains all frequencies,

$$
f_{0}+i \times \Delta f, \quad n=\left[\frac{f_{1}-f_{0}}{\Delta f}\right], \quad i=0, \ldots, n,
$$

with the exception of the forbidden ones, which are specified by their enumeration or in the form of intervals. Here:

$f_{0}$ - the lower limit of the permissible frequencies,

$f_{1}$ - the upper limit of the permissible frequencies,

$\Delta f$ - the minimum difference between the basic values of frequencies,

$[\cdot]$ - means the whole fraction.

Depending on the number of prohibited frequencies, the total number of $F$ will be a certain number $M \leq n$.

Let the total number of zones (territories) within which it is planned to distribute frequencies be $N$.

Let's number these zones from 1 to $N$ and denote by $A_{k}$ and $B_{k}$, accordingly, the set of radio frequencies that are used by radio stations at the current moment and the set of radio frequencies that are to be allocated by radio stations in the zone with the number $k$, where $k=1,2, \ldots, N$.

Let's denote by $\mathfrak{I}_{k}$ the set of indices of the broadcasting zones that have an adjacent (common) border with the zone number $k$. Obviously, for different $k$, the number of elements may be different.

For example,

$$
\mathfrak{I}_{1}=\{2,3,4,6\}, \mathfrak{I}_{2}=\{1,3,4\} \text { etc. }
$$

Let's denote an operator generating a random subset of a given set in the number of $m$ elements with $\mathfrak{R}(m)$, where $m$ is not more than the total number of elements of the original set.
The principle of generating new parts by zones is based on the selection of random frequencies from among those allowed for this zone, with the exception of frequencies used in this zone at the current moment and coincidence with the frequencies of adjacent zones. It is easy to see that such a selection of frequencies can be implemented as follows:

$$
\begin{gathered}
\mathfrak{R}(m): F \backslash A_{1} \rightarrow B_{1}, \\
k=2, \ldots, N, \\
\mathfrak{R}(m): F \backslash A_{k} \backslash \bigcup_{j<k, j \in \mathfrak{I}_{k}} B_{j} \rightarrow B_{k} .
\end{gathered}
$$

Thus, the result of applying this algorithm is the set $B_{k},(k=1,2, \ldots, N)$, representing a set of new frequencies.

While the described algorithm provides nonrepeatable frequencies of adjacent zones, it also allows the use of the same frequencies in non-adjacent zones, thereby increasing the choice in allocating frequencies to zones.

\section{Conclusion}

Thus, we have studied the problem of assigning radio frequencies from among those assigned for corporate use by organizations. It was shown that any territory can be divided into zones, each of which will have a border with only three other zones.

In this case, in each zone, you can assign frequencies in the amount of a quarter of the total number of available frequencies that do not overlap with the frequencies assigned in adjacent zones.

A mathematical model of the problem of radio frequency redistribution has been built, taking into account the regulations and the geographical location of the operation units. The implementation algorithm makes it possible to take into account the history of frequency distribution by zones, which allows you to completely update the used radio frequencies for a new service life.

A software module has been compiled that generates frequencies for assigning corporate use for each zone. The software module allows fast and frequent reallocation of frequencies by zones, thereby ensuring the safety, reliability and stability of communication between organizational units.

\section{REFERENCES}

1. Veerpalu, V.E. (2012), "Methods of redistribution and conversion of the radio frequency spectrum", T-Comm: Telecommunications and transport, No. 6, pp. 12-16, available at http://media-publisher.ru/old/pdf/Nom-6-2012-sait.pdf.

2. (2007), Rules for allocation, registration, use and determination of radio frequencies [Rules for the allocation, registration, use and payment of radio signals], approved by the Resolution of the Cabinet of Ministers of Azerbaijan Republic No. 22 dated 01.02.2007, available link http://www.dri.az/view.php?lang=en\&menu=8075\&id=1590

3. (2000), The national table is broken by the low radio frequency of Ukraine, VR Ukraine, Law "On Radio Frequency Resources of Ukraine" 01.06.2000 N 1770-III.

4. (2006), Table of distribution of frequency bands between the radio services of the Russian Federation, Resolution of the Government of the Russian Federation of 15.07.2006, No. 439-23, available at the link http://www.grfc.ru/grfc/sprav_info/tabl_chastot

5. Ryszard, Struzak, Terje, Tjelta and Jose P., Borrego (2015), "On Radio-Frequency Spectrum Management”, The Radio Science Bulletin, No. 354 (September 2015), pp. 11-34. 
6. Ron, Davies (2015), "Radio spectrum: A key resource for the Digital Single Market", European Parliamentary Research Service, Briefing, March -2015, 8 p.

7. (2018), Analysis and assessment of global trends in the use of the radio frequency spectrum by various radio communication services, available at the link http://minsvyaz.ru/uploaded/files/kontseptsiya-radiokontrolya-prilozhenie-2.pdf.

8. Buzov, A.L., Bykhovsky, M.A., Vaseho, N.V., Volkova, Yu.V., Zhiltsov, A.U., Ivanova, T.V., Nosov, V.I., Sevostyanov, S.V., Sorokin, A.S. and Sorokin G.I. (376), Management of the radio frequency spectrum and electromagnetic compatibility of radio systems, Tutorial, Eco-Trends, Moscow,376 p.

9. Grishchenko, O.Yu. and Onotsky, V.V. (2015), Course of lectures on complex analysis. Part one, Kyiv, 143 p.

10. Fedak, I.V. (2020), Course of lectures on functional analysis and theory of measure. Tutorial. Part 3. Basic structures of functional analysis, PNU named after Vasyl Stefanyk, Ivano-Frankivsk, 48 p.

Received (Надійшла) 22.02.2021

Accepted for publication (Прийнята до друку) 21.04.2021

\section{ВІДОМОСТІ ПРО АВТОРІВ / АВOUT THE AUTHORS}

Пашаев Адалат Бахтияр - кандидат фізико-математичних наук, старший дослідник, завідувач лабораторії, Інститут систем управління Національної академії наук Азербайджану, Баку, Азербайджан;

Adalat Bakhtiyar Pashayev - Candidate of Physics and Mathematics, Head of laboratory, Control Systems Institute of Azerbaijan National Academy of Sciences; Baku, Azerbaijan;

e-mail: adalat.pashayev@ gmail.com,ORCID ID: http://orcid.org/0000-0001-9208-8430.

Сабзісв Ельхан Наріман оглу - кандидат фізико-математичних наук, доцент, Інститут систем управління Національної академії наук Азербайджану, Баку, Азербайджан,

Elhan Nariman oglu Sabziev - Candidate of Physics and Mathematics, Associate Professor, Institute of Control Systems of Azerbaijan National Academy of Sciences; e-mail: elkhan.sabziev@gmail.com, ORCID ID: http://orcid.org/0000-0001-8150-9439.

Гасанов Аріф Гасан огли - кандидат національної безпеки і військових наук, доцент, Військова Академія Збройних Сил Азербайджанської Республіки, Баку, Азербайджан,

Arif Hasan oğlu Hasanov - PhD in National security and Military Sciences, Associate Professor, War College of the Armed Forces of the Republic of Azerbaijan, Baku Azerbaijan; e-mail: Arif.H.Hasanov@gmail.com,ORCID ID: http://orcid.org/0000-0002-8814-1590.

\section{Завдання перерозподілу радіочастот, що використовуються в підрозділах експлуатації}

А. Б. Пашаєв, Е. Н. Сабзієв, А. Г. Гасанов

Анотація. В роботі розглядається задача розподілу радіочастот, з урахуванням регламентів і географічного розташування підрозділів експлуатації. Досліджено задачу призначення радіочастот з числа заданих для корпоративного користування. Застосуванням конформного відображення було обгрунтовано, що будь-яку територію можна розбити в зони кожна з яких матиме кордон тільки з трьома іншими зонами. При цьому в кожній зоні можна призначити частоти в кількості однієї чверті від кількості доступних частот, які не перетинаються з частотами, призначеними в суміжні зони. Побудовано математичну модель задачі перерозподілу радіочастот, з урахуванням регламентів і географічного розташування підрозділів. Алгоритм реалізації дозволяє враховувати історію розподілу частот по зонам, що дозволяє повністю оновити використовувані радіочастоти до нового терміну експлуатації. Складено програмний модуль, який генерує частоти випадковим чином 3 числа доступних для призначення корпоративного користування по кожній зоні. Програмний модуль дозволяє швидке та часте перерозподіл частот по зонам, тим самим забезпечує безпеку, надійність $\mathrm{i}$ стійкість зв'язку між підрозділами організації.

Кл юч ов і сл ов а: перерозподіл радіочастот; радіочастотний спектр; діапазон радіочастот; алгоритм; географічне розташування; суміжні зони.

\section{Задача перераспределения радиочастот, используемых в подразделениях эксплуатации \\ А. Б. Пашаев, Э. Н. Сабзиев, А. Г. Гасанов}

Аннотация. В работе рассматривается задача распределения радиочастот, с учетом регламентов и географического расположения подразделений эксплуатации. Исследована задача назначения радиочастот из числа заданных для корпоративного пользования. Применением конформного отображения было обосновано, что любую территорию можно разбить в зоны каждая из которых будет иметь границу только с тремя другими зонами. При этом в каждой зоне можно назначить частоты в количестве одной четверти из общего количества доступных частот, которые не пересекаются с частотами, назначенными в смежные зоны. Построена математическая модель задачи перераспределения радиочастот, с учетом регламентов и географического расположения подразделений. Алгоритм реализации позволяет учитывать историю распределения частот по зонам, что позволяет полностью обновить используемые радиочастоты к новому сроку эксплуатации. Составлен программный модуль, который генерирует частоты случайным образом из числа доступных для назначения корпоративного пользования по каждой зоне. Программный модуль позволяет быстрое и частое перераспределение частот по зонам, тем самым обеспечивает безопасность, надежность и устойчивость связи между подразделениями организации.

Ключевые слов : п перераспределение радиочастот; радиочастотный спектр; диапазон радиочастот; алгоритм; географическое расположение; смежные зоны. 